\section{PENGARUH GENDER, INTELLIGENT QUOTIENT (IQ), EMOTIONAL QUOTIENT (EQ) DAN SPIRITUAL QUOTIENT (SQ) TERHADAP PERTIMBANGAN PEMBERIAN OPINI AUDITOR}

\author{
Maylani Suprihatin, Endang Dwi Wahyuni, \\ Eris Tri Kurniawati \\ Prodi Akuntansi FEB Universitas Muhammadiyah Malang \\ Jl. Raya Tlogomas 246 Malang. \\ Email: yuni.latifah14@gmail.com
}

\begin{abstract}
$A B S T R A C T$
The purpose of this study is to examine the effect of gender, intelligent quotient, emotional quotient and spiritual quotient on the judgment of the auditor's opinion. Therefore, researcher uses a quantitative methods with SPSS as an analytical tool in this study. The results show that men and women do not have a significant difference based on psychological aspects that say women have a tendency to be more efficient and more thorough in decision making. On the other hand, The higher of intellectual and emotional intelligence then giving the auditor's opinion will also increase well. Another finding is the higher of spiritual intelligence the more he can survive in the face of difficulties during performing his duties so that it will affect the conclusions of the examination set forth in the opinion of auditors
\end{abstract}

Keywords: Auditors Opinion, Emotional Quotient, Gender, Intellegent Quotient, Spiritual Quotient.

\section{PENDAHULUAN}

Peraturan BAPEPAM Nomor Kep-36/PM/2003 dan Peraturan Bursa Efek Jakarta (BEJ) Nomor Kep-306/BEJ/07-2004 menyebutkan bahwa perusahaan yang go public diwajibkan menyampaikan laporan keuangan yang disusun sesuai dengan Standar Akuntansi Keuangan (SAK) dan telah diaudit oleh akuntan publik. Setiap profesi membutuhkan pengetahuan dan keahlian khusus, dan setiap profesional diharapkan memiliki kualitas personal tertentu. Demikian pula halnya dengan profesi akuntan publik yang bekerja di kantor akuntan publik (KAP). Seiring dengan berjalannya waktu, beberapa perusahaan atau organisasi tentunya memiliki pesaing yang semakin lama semakin bermunculan. Salah satu cara agar perusahaan atau organisasi dapat bersaing, bertahan serta melawan para pesaingnya, organisasi atau perusahaan harus mampu menunjukkan bahwa kinerja maupun keuangan perusahaannya mempunyai prospek ke depan yang baik dan menjanjikan.

Wijayanti (2012) menyatakan bahwa kepercayaan investor merupakan hal yang tidak dapat dibeli, sehingga diperlukan peran auditor sebagai pihak yang mengevaluasi dan memberikan opini atau pendapat mengenai kewajaran laporan keuangan. Hal tersebut dilakukan agar laporan keuangan perusahaan dapat disajikan secara handal dan relevan serta dapat dipertanggungjawabkan. Di dalam mengaudit laporan keuangan klien hingga dapat mengeluarkan sebuah opini audit, terlebih dahulu kantor akuntan publik (KAP) akan mengirimkan satu tim yang didalamnya terdapat ketua tim untuk turun ke lapangan guna melakukan 
Pengaruh Gender, Intelligent Quotient...

886 pemerikasaan. Kemudian dibuat kertas kerja pemeriksaan yang nantinya akan didiskusikan dan dipertimbangkan dalam rapat tim audit bersama seorang supervisor. Hasil pembahasan tersebut akan mengeluarkan sebuah opini yang akan diserahkan kepada klien untuk disetujui. Jadi auditor yang bergabung dalam tim dapat mengumpulkan bukti yang terkait dengan laporan keuangan klien, yang nantinya akan menentukan pemberian opini audit.

Gender diduga menjadi salah satu faktor level individu yang turut mempengaruhi audit judgment seiring dengan terjadinya perubahan pada kompleksitas tugas dan pengaruh tingkat kepatuhan terhadap etika. Temuan riset literatur psikologis kognitif dan pemasaran juga menyebutkan bahwa wanita diduga lebih efisien dan efektif dalam memproses informasi saat adanya kompleksitas tugas dalam pengambilan keputusan dibandingkan dengan pria. Pria dipandang memiliki sifat kuat dan keras, yang memiliki konotasi positif, sedangkan wanita dipandang memiliki sifat lemah lembut yang memiliki konotasi negatif dilingkungan pekerjaan (Nelson, 1992).

Chung dan Monroe (2001) melakukan studi pengaruh gender dan kompleksitas tugas pada akurasi pertimbangan audit. Hasilnya ternyata ada interaksi yang signifikan antara gender dan kompleksitas tugas pada akurasi pertimbangan audit. Hasil ini menunjukkan bahwa perempuan lebih akurat dalam judgment dibanding laki-laki dalam mengerjakan tugas yang lebih kompleks, namun ketika kompleksitas tugas berkurang, laki-laki menunjukkan hasil yang lebih baik Dengan demikian kecerdasan intelektual akan mempengaruhi kemampuan auditor untuk melakukan pemeriksaan audit dengan baik. Kecerdasan intelektual merupakan kecerdasan untuk menerima, menyimpan dan mengolah informasi menjadi fakta. Auditor yang kecerdasan intelektualnya baik, baginya tidak ada informasi yang sulit, semuanya dapat disimpan dan diolah dengan cepat dan tepat. Pada saat informasi tersebut dibutuhkan, dengan mudah auditor menginformasikan kembali kepada klien sesuai dengan informasi yang telah diolah.

Di sisi lain, auditor juga memerlukan kecerdasan emosional untuk membantu dalam melakukan pemeriksaan guna mendeteksi kebenaran atas laporan keuangan yang disajikan klien. Sejalan dengan yang diungkapkan Wijayanti (2012), bahwa kecerdasan emosional akan mempermudah seorang auditor untuk melakukan pemeriksaan, memiliki motivasi yang kuat, mengontrol diri/emosi, rasa empati serta keterampilan dalam bersosialisasi akan membantu auditor dalam menelusuri buktibukti audit serta informasi terkait. Menurut Boyatzis, Goleman dan Rhee (2000), makin kompleks pekerjaan, makin penting kecerdasan emosi. Emosi yang lepas kendali dapat membuat orang pandai menjadi bodoh. Tanpa kecerdasan emosi, seseorang tidak akan mampu menggunakan kemampuan afeksi atau sikap mereka yang sesuai dengan potensi yang maksimum.

Auditor yang memiliki pemahaman atau kecerdasan spiritual yang tinggi, akan mampu bertindak atau berperilaku etis dalam profesi dan organisasinya. Apabila auditor tidak memiliki kemampuan spiritual yang tinggi, maka auditor tersebut bisa saja melakukan hal yang menyimpang misalnya saja tidak jujur. Profesi akuntan dituntut untuk memiliki integritas dan kejujuran agar obyektif. Auditor bisa saja tidak jujur karena mendapat honor lebih dari klien. Oleh karena itu SQ (Spiritual Quotient) merupakan landasan yang diperlukan untuk memfungsikan IQ (Intelligence Quotient) dan EQ (Emotional Quotient) secara efektif. Secara singkat kecerdasan spiritual mampu mengintegrasikan dua kemampuan lain yang terdiri dari kecerdasan intelektual dan kecerdasan emosional (Idrus 2002). Dengan demikian adanya gender, Emotional Quotient(EQ), Spiritual Quotient (SQ), Intelligence Quotiont (IQ) tersebut seorang auditor diharapkan dapat berbuat tegas dalam memberikan opini yang tepat mengenai laporan keuangan kliennya walaupun dalam keadaan tertekan.

Seorang auditor dalam melakukan tugasnya yaitu membuat dan menghasilkan opini audit atau audit judgment dipengaruhi oleh banyak faktor, baik bersifat teknis ataupun non teknis. Aspek perilaku individu, sebagai salah satu 
faktor yang banyak mempengaruhi pembuatan audit judgment, saat ini semakin banyak mencuri perhatian dari para praktisi ataupun akademisi akuntansi. Namun demikian, meningkatnya perhatian tersebut tidak diimbangi dengan pertumbuhan penelitian di bidang akuntansi perilaku di mana dalam banyak penelitian tidak menjadi fokus utama (Meyer, 2001). Cara pandang auditor dalam menanggapi informasi berhubungan dengan tanggung jawab dan risiko audit yang akan dihadapi oleh auditor sehubungan dengan judgment yang dibuatnya. Faktor-faktor yang mempengaruhi persepsi auditor dalam menanggapi dan mengevaluasi informasi ini antara lain meliputi faktor pengetahuan, perilaku auditor dalam memperoleh dan mengevaluasi informasi, serta kompleksitas tugas dalam melakukan pemeriksaan.

Penelitian ini dimaksudkan untuk mengetahui apakah faktor gender dan tekanan ketaatan juga akan mempengaruhi persepsi auditor. Di Indonesia penelitian tentang pemberian opini auditor telah banyak dilakukan dengan menggunaka variabel-variabel yang berbeda. Penelitian tentang Intelligent Quotient (IQ), Emotional Quotient (EQ) dan Spiritual Quotient (SQ) telah dilakukan oleh Sukmawati (2014) dan Yulianti (2015) mengatakan bahwa semua variabel tersebut sangat berpengaruh terhadap pemberian opini auditor. Hal ini menegaskan bahwa setiap pribadi berbeda dari auditor sangat berpengaruh terhadap keputusan yang dibuat. Berdasarkan latar belakang tersebut, maka peneliti mengkonstruksi tujuan penelitian ini yaitu untuk menganalisis pengaruh Gender, Intelligent Quotient (IQ), Emotional Quotient (EQ) dan Spiritual Quotient (SQ) Terhadap Pertimbangan Pemberian Opini Auditor. Peneliti menyususn beberapa hipotesis penelitian berdasar pada penelitian sebelumnya yaitu:

$\mathrm{H}_{1}$ : Gender berpengaruh terhadap pertimbangan pemberian opini Auditor.

$\mathrm{H}_{2}$ : Intelligence Quotient (IQ) berpengaruh terhadap pertimbangan pemberian opini auditor.

$\mathrm{H}_{3}$ : Emotional Quotient (EQ) berpengaruh terhadap pertimbanganpemberian opini auditor.

$\mathrm{H}_{4}$ : Spiritual Quotient (SQ) berpengaruh terhadap pertimbangan pemberian opini auditor.

\section{METODE}

Penelitian asosiatif ini mengambil beberapa sampel dari seluruh populasi. Populasi pada penelitian ini ialah Auditor pada Kantor Akuntan Publik di Malang. Teknik sampling digunakan dalam penelitian ini dengan kriteria yaitu auditor sudah pernah bergabung dalam tim audit. Data yang digunakan dalam penelitian ini adalah data primer yaitu data yang diperoleh secara langsung dan khusus dari responden, melalui teknik kuesioner. Teknik analisis data yang disusun peneliti yaitu: (1) melakukan analisis deskriptif variabel responden, (2) melakukan analisis statistik deskriptif, (3) melakukan analisis uji kualitas data, (4) melakukan analisis uji asumsi klasik, dan (5) melakukan pengujian hipotesis.

Pertama, peneliti akan melakukan analisis deskriptif variabel responden guna mengetahui karakteristik responden dalam penelitian yang dijadikan sampel. Karakteristik responden dilihat dari Gender, Intelligent Quotient(IQ), Emotional Quotient(EQ), Spiritual Quotient (SQ). Kedua, peneliti melakukan analisis statistik deskriptif untuk mendapatkan gambaran umum responden dengan menggunakan tabel distribusi yang merincikan mengenai variabel-variabel keseluruhan dalam penelitian dimana didapatkan dari jawaban responden yang diterima. Statistik yang digunakan antara lain nilai minimum, maksimum, nilai. Ketiga, peneliti melakukan uji kualitas data, dimulai dari uji validitas, reliabilitas hingga normalitas untuk memastikan bahwa data penelitian tersebut valid, reliable dan berdistribusi normal. Keempat, peneliti melakukan analisis uji asumsi klasik. Uji asumsi klasik 
Pengaruh

Gender, Intelligent

Quotient...

888 ini termasuk didalamnya yaitu uji multikolinieritas dan heteroskedastisitas. Kedua uji tersebut dilakukan agar data bebas dari "penyakit" penyimpangan asumsi klasik multikolinearitas dan "penyakit" redsidual memiliki varians yang sama. Terakhir, peneliti akan melakukan uji hipotesis. Dalam menganalisis hipotesis penelitian ini, metode yang digunakan adalah Uji Linier Berganda. Uji Linier Berganda adalah hubungan secara linier antara dua atau lebih variabel independen yaitu gender (X1), kecerdasan intelektual (X2), kecerdasan emosional (X3), kecerdasan spiritual (X4) dengan variabel dependen yaitu pertimbangan pemberian opini auditor (Y).

\section{HASIL DAN PEMBAHASAN}

Penelitian ini dilakukan pada Kantor Akuntan Publik yang berada di Kota Malang meliputi KAP Doli, Bambang, Sulistiyanto, Dadang \& Ali (cabang), KAP Krisnawan, Busroni, Achsin \& Alamsyah (cabang), KAP Made Sudarma, Thomas \& Dewi, KAP Drs. Nasikin, KAP Suprihadi dan Rekan, KAP Thoufan dan Rosyid. Dari hasil pencarian http://iapi.or.id/detail/42-Malang dan observasi langsung peneliti, jumlah populasi Kantor Akuntan Publik di Kota Malang sebanyak 8 KAP dengan alamat dan nama Kantor Akuntan Publik (terlampir). Alasan peneliti mengambil 6 Kantor Akuntan Publik di kota Malang dari 8 Kantor Akuntan Publik 2 diantaranya tidak menerima pengisian kuisioner.

\begin{tabular}{clccc}
\hline No. & Nama Kantor Akuntan Publik & $\begin{array}{c}\text { Jumlah } \\
\text { Auditor }\end{array}$ & $\begin{array}{c}\text { Jumlah } \\
\text { disebar }\end{array}$ & $\begin{array}{c}\text { Jumlah } \\
\text { diterima }\end{array}$ \\
\hline 1. & $\begin{array}{l}\text { Doli, Bambang, Sulistiyanto, } \\
\text { Dadang \& Ali (cabang) }\end{array}$ & 15 & 14 & 13 \\
2. & $\begin{array}{l}\text { Krisnawan, Busroni, Achsin \& } \\
\text { Alamsyah (cabang }\end{array}$ & 13 & 12 & 11 \\
3. & Made Sudarma, Thomas \& Dewi & 15 & 15 & 13 \\
4. & Drs. Nasikin & 13 & 12 & 10 \\
5. & Suprihadi dan Rekan & 10 & 10 & 9 \\
6. & Thoufan dan Rosyid & 20 & 16 & 15 \\
& Jumlah & & 79 & 71 \\
\hline
\end{tabular}

Sumber: data primer yang diolah 2015

\section{Variabel IQ, EQ dan SQ}

Berdasarkan hasil ouput SPSS, Pertimbangan Pemberian Opini Auditor (Y) memiliki rata-rata sebesar 4,3239 dengan nilai standar deviasi 0,61457 artinya responden cenderung menjawab setuju dan memiliki keseragaman jawaban. Begitu pula untuk Variabel Intellektual Quotient (X2), Variabel Emotional Quotient (X3), Variabel Spiritual Quotient (X4) masing-masing memiliki nilai rata-rata sebesar 4.2012 (standar deviasi 0.43771), nilai rata-rata 3.9838 (standar deviasi), dan nilai rata-rata 3.6479 dengan standar deviasi 0,25278 .

Hasil dari penyebaran kuisioner kepada seluruh akuntan publik yang ada di kota malang, menunjukkan bahwa akuntan publik yang berjenis kelamin perempuan lebih banyak dari pada akuntan publik laki-laki. Hasil grafik menunjukkan bahwa dari 71 responden, $58 \%$ atau sebanyak 42 responden berjenis kelamin Perempuan. Sedangkan $42 \%$ atau sebanyak 29 responden berjenis kelamin laki-laki. Di sisi lain, jawaban responden tentang Intelligen Quotien (IQ) yang diproksikan dalam bentuk kemampuan berbahasa dan kemampuan berlogika menunjukkan hasil beragam. Rata-rata indikator X2.1 (Kemampuan Bahasa) sebesar 4.230 menunjukkan bahwa indikator X2.1 (Kemampuan Bahasa) berada pada kriteria baik. Begitu pula rata-rata indikator X2.2 (Kemampuan Logika) sebesar 4.180 
menunjukkan bahwa indicator X2.2 (Kemampuan Logika) juga berada pada kriteria baik.

Proksi tentang Emotional Quotent (EQ) dibagi ke dalam bentuk pengendalian diri, empati, motivasi dan ketrampilan sosial. Rata-rata indikator X3.1 (Pengenalan Diri) sebesar 4.192 menunjukkan bahwa indikator X3.1 (Pengenalan Diri) berada pada kriteria baik. Selain itu, beberapa proxy lain seperti X3.2 (Pengendalian Diri), X3.3 (empati), X3.4 (Motivasi) dan X3.5 (Keterampilan Sosial) juga berada pada posisi kriteria yang baik dimana masing-masing memiliki rata-rata indikator 3.873, 3.976, 3.904, dan 3.937.

\section{Variabel Pertimbangan Pemberian Opini Auditor}

Hasil perhitungan menunjukkan bahwa dari 71 responden, 46.5\% menyatakan setuju bahwa Auditor memiliki kemahiran dalam ketepatan pemberian opini audit. Dan $40.8 \%$ responden menyatakan sangat setuju bahwa Auditor memiliki kemahiran dalam ketepatan pemberian opini audit. Rata-rata keseluruhan item ini adalah sebesar 4.282. Dengan demikian rata-rata responden setuju bahwa Auditor Memiliki kemahiran dalam ketepatan pemberian opini audit. Opini audit harus sesuai dengan bukti audit dari 71 responden, $52.1 \%$ menyatakan sangat setuju bahwa Opini audit harus sesuai dengan bukti audit yang ada. Dan 36.6\% responden menyatakan setuju bahwa Opini audit harus sesuai dengan bukti audit yang ada. Rata-rata keseluruhan item ini adalah sebesar 4.394. Dengan demikian rata-rata responden setuju bahwa Opini audit harus sesuai dengan bukti audit yang ada.

Bukti yang didapatkan cukup sehingga tepat dalam memberikan opini audit dari 71 responden, 50.7\% menyatakan setuju bahwa Bukti yang didapatkan cukup sehingga tepat dalam memberikan opini audit. Dan 39.4\% responden menyatakan sangat setuju bahwa Bukti yang didapatkan cukup sehingga tepat dalam memberikan opini audit. Rata-rata keseluruhan item ini adalah sebesar 4.296. Dengan demikian rata-rata responden setuju bahwa Bukti yang didapatkan cukup sehingga tepat dalam memberikan opini audit.

\section{Uji Validitas, Reliabilitas dan Normalitas}

Berdasarkan hasil uji validitas yang dilakukan dengan bantuan SPSS, menunjukkan bahwa $r$ hitung $>r$ tabel. $\mathrm{R}$ hitung yaitu bagian Corrected Item Total Correlation dan $r$ tabel dengan ketentuan 71-2 dengan tingkat signifikasi sebesar 5\% diperoleh $r$ tabel sebesar 0,2319. Seluruh pernyataan dalam variabel tersebut memiliki nilai lebih besar dari $r$ tabel 0.2319 dan bernilai positif sehingga dapat disimpulkan bahwa seluruh konstruk pernyataan adalah valid dan dapat dipergunakan sebagai alat pengumpul data dalam penelitian ini. Selain itu, berdasarkan hasil uji reabilitas menunjukkan bahwa nilai Cronbach Alpha yaitu 0.906. Nilai $0.906>0.70$ artinya konstruk atau variabel pada kuisioner adalah reliable sehingga variabel tersebut dinyatakan handal dan layak dipergunakan sebagai alat pengumpul data. Peneliti telah melakukan uji normalitas menggunakan metode Kolmogorov Smirnov dengan bantuan program SPSS, maka diperoleh nilai Kolmogorov Smirnov adalah 0,393 dan signifikan 0,998, karena nilai signifikan Kolmogorov Smirnov yaitu 0.998>0,05 maka data berdistribusi secara normal.

\begin{tabular}{|c|c|}
\hline Cronbach's Alpha & $\mathrm{N}$ of Items \\
\hline .906 & 47 \\
\hline
\end{tabular}

Tabel 2

Reliability Statistics

Sumber: Data diolah 2015 


\section{Pengaruh \\ Gender, Intelligent Quotient...}

890

Tabel 3 Hasil Uji Multikolinieritas

\section{Uji Asumsi Klasik}

Multikolinieritas digunakan untuk mengetahui ada tidaknya hubungan antar variabel bebas. Pada asumsi ini diharapkan dapat dilakukan dengan melihat nilai Variance Inflation Factor (VIF) dari masing-masing variabel bebas terhadap variabel terikatnya. Jika nilai VIF tidak lebih dari 10 maka model dinyatakan tidak terdapat gejala multikolinier. Berdasarkan output data SPSS menunjukkan bahwa semua variabel mempunyai nilai VIF yang tidak lebih dari 10, sehingga model regresi yang terbentuk tidak mengandung gejala multikolinier.

Di sisi lain, peneliti juga menngunakan asumsi heteroskedastisitas untuk mengetahui apakah residual memiliki ragam yang homogen (konstan) atau tidak. Pengujian asumsi heteroskedastisitas diharapkan residual memiliki ragam yang homogen. Pengujian asumsi heterokedastisitas dapat dilihat melalui scatter plot. Residual dikatakan memiliki ragam yang homogen apabila titik-titik residual pada scatter plot menyebar secara acak. Berdasarkan scatter plot, titik-titik residual menyebar secara acak sehingga dapat disimpulkan bahwa residual memiliki ragam yang homogeny yang artinya asumsi heteroskedastisitas terpenuhi.

\begin{tabular}{lcc}
\hline Variabel Bebas & Tolerance & VIF \\
\hline Gender & 0.985 & 1.105 \\
Intelligence Quotient (IQ) & 0.838 & 1.193 \\
Emotional Quotient $(E Q)$ & 0.801 & 1.248 \\
Spiritual Quotient $(S Q)$ & 0.786 & 1.272 \\
\hline
\end{tabular}

Sumber: Data diolah 2015

\section{Regresi Linier Berganda}

Penelitian ini menggunakan empat variabel independen yaitu variabel Gender, variabel Intelligence Quotient (IQ), variabel Emotional Quotient (EQ) dan variabel Spiritual Quotient (SQ). Variabel dependen dalam penelitian ini adalah Pertimbangan Pemberian Opini Auditor. Berikut adalah model regresi linier berganda:

$\mathrm{Y}=\beta 0+\beta 1 \mathrm{X} 1+\beta 2 \mathrm{X} 2+\beta 3 \mathrm{X} 3+\beta 4 \mathrm{X} 4+\varepsilon$

$\mathrm{Y}=-3.048-0.097 \mathrm{X} 1+0.618 \mathrm{X} 2+0.793 \mathrm{X} 3+0.459 \mathrm{X} 4$

Persamaan ini menunjukkan hal-hal sebagai berikut: Pertama, Konstanta sebesar -3.048 mengindikasikan bahwa apabila variabel Gender, Intelligence Quotient (IQ), Emotional Quotient (EQ) dan Spiritual Quotient (SQ) bernilai konstan maka besarnya perubahan Pertimbangan Pemberian Opini Auditor sebesar -3.048. Kedua, Koefisien Gender sebesar -0.097 mengindikasikan bahwa Gender laki-laki yang lebih meningkatkan perubahan Pertimbangan Pemberian Opini Auditor daripada perempuan. Hal ini berarti Gender laki-laki cenderung meningkatkan perubahan Pertimbangan Pemberian Opini Auditor lebih besar 0.097 dibandingkan perempuan. Namun peningkatan ini tidak signifikan.

Ketiga, Koefisien Intelligence Quotient (IQ) sebesar 0.618 mengindikasikan bahwa Intelligence Quotient (IQ) berpengaruh positif terhadap perubahan pertimbangan pemberian opini Auditor. Hal ini berarti meningkatnya Intelligence Quotient (IQ) maka cenderung dapat meningkatkan perubahan Pertimbangan Pemberian Opini Auditor. Keempat, koefisien Emotional Quotient (EQ) sebesar 0.793 mengindikasikan bahwa Emotional Quotient (EQ) berpengaruh positif terhadap perubahan Pertimbangan Pemberian Opini Auditor. Hal ini berarti meningkatnya Emotional Quotient (EQ) maka cenderung dapat meningkatkan perubahan pertimbangan pemberian opini Auditor. Kelima, koefisien Spiritual Quotient (SQ) sebesar 0.459 mengindikasikan bahwa Spiritual Quotient (SQ) berpengaruh positif terhadap perubahan Pertimbangan Pemberian Opini Auditor. Hal ini berarti 
meningkatnya Spiritual Quotient (SQ) maka cenderung dapat meningkatkan perubahan Pertimbangan Pemberian Opini Auditor.

\section{Uji F (Pengujian Menyeluruh atau Simultan)}

Pengujian signifikansi simultan digunakan untuk mengetahui ada tidaknya pengaruh Gender, Intelligence Quotient (IQ), Emotional Quotient (EQ) dan Spiritual Quotient (SQ) terhadap Pertimbangan Pemberian Opini Auditor. Pengujian signifikansi secara simultan menghasilkan nilai Fhitung $=26.447$ dengan probabilitas 0.000. Hasil pengujian tersebut menunjukkan probabilitas < level of significance $(\mathrm{a}=5 \%)$. Hal ini berarti terdapat pengaruh signifikan secara simultan (bersama-sama) Gender, Intelligence Quotient (IQ), Emotional Quotient (EQ) dan Spiritual Quotient (SQ) terhadap pertimbangan pemberian opini Auditor.

\section{Pengaruh Gender Terhadap Pertimbangan Pemberian Opini Auditor}

Hasil penelitian ini adalah tidak terdapat pengaruh Gender terhadap Pertimbangan Pemberian Opini Auditor. Oleh karena itu, hasil penelitian ini mendukung penelitian yang dilakukan oleh Hartanto (2001). Namun demikian, hasil penelitian ini tidak sejalan dengan hasil penelitian yang dilakukan oleh Chung dan Monroe (2001) yang menyatakan bahwa Gender berpengaruh secara signifikan terhadap Pertimbangan Pemberian Opini Auditor. Penelitian ini menunjukkan bahwa antara laki-laki dan perempuan tidak memiliki perbedaan yang signifikan berdasarkan segi psikologis yang mengatakan bahwa perempuan memiliki kecenderungan lebih efisien dan lebih teliti dalam pengambilan keputusan. Ada kemungkinan responden dalam penelitian ini didominasi oleh auditor perempuan. Penelitian ini menunjukkan bahwa perbedaan jenis kelamin antara lakilaki dan perempuan dengan perbedaan berbagai sifat dan karakter individu masingmasing tidak berpengaruh terhadap pertimbangan pemberian opini auditor yang diambil oleh auditor laki-laki dan perempuan.

\section{Pengaruh Intelligence Quotient (IQ) Terhadap Pertimbangan Pemberian Opini Auditor}

Hasil penelitian ini menunjukkan bahwa terdapat pengaruh Intelligence Quotient terhadap Pertimbangan Pemberian Opini Auditor sehingga hasil penelitian ini mendukung hasil penelitian yang dilakukan oleh Sukmawati (2014) yang menyatakan bahwa Intelligence Quotient berpengaruh positif dan signifikan terhadap Pemberian Opini Auditor. Kecerdasan intelektual merupakan suatu keharusan yang wajib dimiliki oleh seorang auditor dalam melaksanakan tugas profesional yang dibebankan kepadanya, karena tugas tersebut merupakan suatu tugas yang menuntut daya analisis tinggi serta proses berpikir rasional dalam pemecahan masalah yang mungkin ditemui dalam setiap penugasan yang mereka terima. Oleh karena itu, jika auditor memiliki tingkat kemampuan intelektual yang tinggi, maka kinerja yang akan mereka capai juga akan semakin baik.

\section{Pengaruh Emotional Quotient (EQ) terhadap pertimbangan pemberian opini auditor.}

Berdasarkan output SPSS pada penelitian ini, menunjukkan bahwa terdapat pengaruh Emotional Quotient terhadap Pertimbangan Pemberian Opini. Oleh karena itu, hasil penelitian ini mampu mendukung penelitian yang dilakukan oleh Yulianti (2015), yang menyatakan bahwa Emotional Quotient berpengaruh positif signifikan terhadap Pemberian Opini Auditor. Seorang auditor pasti membutuhkan Emotional Quotient yang tinggi karena dalam lingkungan kerja, auditor berinteraksi dengan banyak orang baik di dalam maupun di lingkungan kerja yang berperan penting dalam membentuk moral dan disiplin kerja. Oleh karena itu, seseorang yang mempunyai kecerdasan emosional yang baik akan 
Pengaruh Gender, Intelligent Quotient... mampu mengetahui serta menangani perasaannya dengan baik, dan mampu menangani perasaan orang lain dengan efektif. Seorang akuntan yang memiliki pemahaman atau kecerdasan emosional yang tinggi akan mampu bertindak dan berperilaku etis dalam profesi (Maryani dan Ludigdo, 2001).

\section{Pengaruh Spiritual Quotient (SQ) Terhadap Pertimbangan Pemberian Opini Auditor.}

Penelitian ini menunjukkan bahwa terdapat pengaruh Spiritual Quotient terhadap Pertimbangan Pemberian Opini Auditor sehingga penenlitian ini bdapat mendukung hasil penelitian yang dilakukan oleh Sukmawati (2014) yang menyatakan bahwa Spiritual Quotient berpengaruh positif dan signifikan terhadap Pemberian Opini Auditor. Seorang auditor haruslah memiliki SQ yang tinggi agar dia dapat benar-benar menjadi pintar. Kecerdasan tersebut juga dibutuhkan dalam dunia kerjanya, apabila ketiga kecerdasan tersebut dapat berfungsi secara efektif maka dia akan menampilkan hasil kerja yang menonjol.

\section{SIMPULAN}

Penelitian ini bertujuan untuk menganalisis pengaruh Gender, Intelligence Quotient (IQ), Emotional Quotient (EQ), serta Spiritual Quotient (SQ) terhadap Pertimbangan Pemberian Opini Auditor. Responden dalam penelitian ini berjumlah 71 orang auditor yang bekerja pada Kantor Akuntan Publik (KAP) di Malang. Berdasarkan hasil analisis data dan pembahasan diatas, maka dapat ditarik kesimpulan bahwa Gender tidak berpengaruh terhadap Pertimbangan Pemberian Opini Auditor pada kantor akuntan publik di Malang. Kondisi ini menunjukkan bahwa perbedaan gender antara auditor laki- laki dan perempuan dengan perbedaan karakter dan sifat yang melekat pada individu masing-masing tidak berpengaruh terhadap pertimbangan pemberian opini audit yang akan diambilnya. Hal ini menunjukkan bahwa antara laki-laki dan perempuan tidak memiliki perbedaan yang signifikan berdasarkan segi psikologis yang mengatakan bahwa perempuan memiliki kecenderungan lebih efisien dan lebih teliti dalam pengambilan keputusan. Di lain pihak, kecerdasan intelektual berpengaruh positif terhadap pertimbangan pemberian opini auditor pada kantor akuntan publik di Malang. Kecerdasan intelektual yang di proksikan dalam kemampuan berbahasa, kemampuan berlogika. Semakin tinggi kecerdasan intelektualnya maka pemberian opini auditor tersebut juga akan meningkat dengan baik. Kecerdasan emosional berpengaruh positif terhadap opini auditor pada kantor akuntan publik di Malang. Kecerdasan emosional yang di proksikan dalam pengendalian diri, empati, motivasi dan ketrampilan sosial. semakin tinggi kecerdasan emosionalnya maka pemberian opini audit dapat dilakukan dengan baik.

Kecerdasan spiritual berpengaruh positif terhadap opini auditor pada kantor akuntan publik di Malang. Kecerdasan spiritual ini ditunjukkan melalui integritas diri dan komitmen yang tinggi. Semakin tinggi kecerdasan spiritualnya semakin membentengi diri auditor untuk berprilaku etis sesuai dengan norma- norma moral. Setelah itu semakin tinggi kecerdasan spiritual semakin mampu ia bertahan dalam menghadapi kesulitan selama melakukan tugasnya sehingga akan mempengaruhi kesimpulan pemeriksaan yang dituangkan dalam opini auditor.

Keterbatasan dalam penelitian ini adalah kurang luasnya populasi yang diambil dan memungkinkan adanya perbedaan kultur di setiap daerah sehingga beberapa hasil penelitian berbeda dengan penelitian terdahulu. Peneliti selanjutnya dapat melakukan penelitian di propinsi lain, sehingga hasilnya bisa digeneralisasi untuk lingkup yang lebih luas. Penelitian selanjutnya disarankan untuk menambah variabel-variabel yang berpengaruh terhadap pertimbangan pemberian opini auditor seperti pengalaman, kemampuan dan pengetahuan. Komponen pengetahuan yang merupakan komponen penting dalam suatu keahlian. 
Chung, J. and G.S. Monroe. 2001. A Research Note on The Effects of Gender and Task Complexity on An Audit Judgment. Behavioral Research in Accounting, 13(1), 111-125.

Boyatzis, R.E., D. Goleman and K. Rhee. 2000. Clustering Competence in Emotional Intelligence: Insights from The Emotional Competence Inventory (ECI). Handbook of emotional intelligence, 99(6), 343-362.

Maryani, T., and U. Ludigdo. 2001. Survei Atas Faktor-Faktor yang Mempengaruhi Sikap dan Perilaku Etis Akuntan. Jurnal Tema, 2(1), 49-62.

Meyer, M. and J.T. Rigsby. 2001. Descriptive Analysis of The Content and Contribution of Behavioral Research In Accounting 1989-1998. Accounting Journal.

Nelson, J.A. 1992. Gender, Metaphor, and The Definition of Economics. Economics \& Philosophy, 8(1), 103-125.

Sandika, K.H. 2011. Pengaruh Pelaksanaan Etika Profesi dan Kecerdasan Emosional Terhadap Pengambilan Keputusan Bagi Auditor. Jurnal jurusan Ekonomi Universitas Diponegoro.

Sukmawati. 2014. Pengaruh Etika Profesi, Kecerdasan Intelektual, Kecerdasan Emosional, dan Kecerdasan Spiritual Terhadap Pemberian Opini Auditor. Jurnal sarjana jurusan Ekonomi Akuntansi Universitas Pendidikan Ganesha.

Wijayanti, G. L. 2012. Peran Kecerdasan Emosional dan Kecerdasan Spiritual falam Meningkatkan Kinerja Auditor. Jurnal Ilmiah Mahasiswa Akuntansi, Vol 1, No.2

Yulianti, A. 2015. Pengaruh Independensi, Intelligence Quotient (IQ), Emotional Quotient (EQ) dan Spiritual Quotient (SQ) terhadap Pertimbangan Pemberian Opini Auditor. jurnal jurusan Ekonomi Universitas Islam Malang. 
